\title{
ASPEK BIOLOGI IKAN TIGAWAJA (Johnius Sp.) YANG DIDARATKAN DI PELABUHAN PERIKANAN PANTAI (PPP) TAWANG KABUPATEN KENDAL
}

\author{
The Biological Aspects of Croackers (Johnius sp.) Landed in Tawang Fish Auction Market Kendal \\ Regency Central Java \\ Syiva Nur Anggraeni, Anhar Solichin*), Niniek Widyorini
}

Program Studi Manajemen Sumberdaya Perairan, Departemen Sumberdaya Akuatik

Fakultas Perikanan dan Ilmu Kelautan, Universitas Diponegoro

Jl. Prof. Soedarto, SH, Tembalang, Semarang, Jawa Tengah - 50275, Telp/Fax. +6224 7474698

Email : syiva.anggraeni50@gmail.com

\begin{abstract}
ABSTRAK
Kabupaten Kendal merupakan salah satu daerah yang berada di pesisir utara Laut Jawa. TPI Tawang merupakan Tempat Pelelangan Ikan (TPI) terbesar di Kabupaten Kendal. Salah satu jenis ikan demersal yang tertangkap di TPI Tawang adalah ikan Tigawaja. Tujuan dari penelitian ini adalah untuk mengetahui aspek biologi Ikan Tigawaja yang didaratkan di TPI Tawang. Penelitian ini dilaksanakan pada bulan Juni 2016. Metode dalam penelitian ini adalah metode survey. Pengambilan sampel menggunakan metode purposive sampling. Hasil penelitian yang dilakukan pada Ikan Ikan Tigawaja sebanyak 390 ekor. Ukuran panjang Ikan Tigawaja dengan kisaran $10,5 \mathrm{~cm}-20,9 \mathrm{~cm}$. Pertumbuhan bersifat allometrik negatif dengan nilai b sebesar 2,8559. Faktor kondisi yang diperoleh sebesar 0,94 yang tergolong dalam ikan pipih. ukuran pertama kali tertangkap $\left(\mathrm{L}_{50 \%}\right)$ adalah $16,4 \mathrm{~cm}$. Tingkat kematangan gonad Ikan Tigawaja jantan didominasi oleh TKG II, sedangkan Tingkat Kematangan gonad Ikan Tigawaja betina didominasi oleh TKG III. Indeks kematangan gonad terendah pada Ikan Tigawaja jantan $0,154 \%$ dan tertinggi $0,465 \%$, sedangkan nilai IKG terendah pada Ikan Tigawaja betina $0,56 \%$ dan tertinggi $8,82 \%$. Ikan Tigawaja jantan dan betina pertama kali matang gonad (Lm) berukuran masingmasing sebesar $18 \mathrm{~cm}$ dan 17,5 cm, artinya Ikan Tigawaja betina lebih cepat matang dari Ikan Tigawaja jantan. Fekunditasnya berkisar antara $15.500-44.148$ butir dan sebaran nilai diameter telur berkisar dari $0,05 \mathrm{~mm}-$ $0,45 \mathrm{~mm}$.
\end{abstract}

Kata Kunci ; Ikan Tigawaja (Johnius sp), Aspek biologi, Perairan Kendal.

\section{ABSTRACT}

Kendal is one area which is on the north coast of Java Sea. The biggest fish auction place in Kendal Regency is Tawang Fish Auction (TPI Tawang). One of kind of demersal fish that caught in TPI Tawang is Croackers Fish. Biological aspect is needed to manage the resources of Croackers Fish. The porpose of this study is to found out the biological aspects of Croackers Fish Landed in Tawang Fish Auction Market. The research did in Juny 2016. The method used in this research is survey method. The sampling was taken by using Purposive sampling. From the research on 390 fish. the length size of Croackers Fish range from $10,5 \mathrm{~cm}-20,9 \mathrm{~cm}$. The growth of served was negative allometric with value of $b 2,8859$. The condition factor of 0,94 are flat fish. size of the first captured fish (L50\%) was 16,4 cm. The Gonad Maturity Level of male Croackers Fish was dominated by TKG II, while for female of Croackers was dominate by TKG III. The lowest Gonad Maturity Index for male of Croackers Fish was 0,154\% dan the hightest was 0,456, while foe female fish the lowest Gonad Maturity Index was $0,56 \%$ and the highest was $8,82 \%$. For both male and female fish, first mature gonad was obtained $18 \mathrm{~cm}$ and $17,5 \mathrm{~cm}$, it means that the female of Croackers Fish was mature faster than the male. The fecundity ranged from 15.500-44.148 item and variance of diameter value range from 0,05 $\mathrm{mm}-0,45 \mathrm{~mm}$.

Key Word; Croackers (Johnius sp), Biological Aspects, Kendal Waters.

\section{*) Penulis Penanggung Jawab}

\section{PENDAHULUAN}

Kabupaten kendal merupakan salah satu daerah yang berada dipesisir utara laut jawa. Luas wilayah Kabupaten Kendal mencapai 1.000,23 km2 dengan panjang garis pantai $41 \mathrm{~km}^{2}$. Secara geografis terletak pada koordinat $06^{0} 32^{\prime}-07^{\circ} .24^{\prime} \mathrm{LS} ; 109^{\circ} 40^{\prime}-110^{\circ} 18^{\prime}$ BT. Tempat Pelelangan Ikan (TPI) yang beroperasi di Kabupaten Kendal berjumlah 4 yaitu TPI Tawang, Sendang Sikucing, Tanggul Malang, dan Bandengan. Salah satu TPI terbesar di Kabupaten Kendal adalah TPI Tawang (Budiman, 2006). 
Ikan Tigawaja termasuk dalam kelompok ikan demersal. Ikan ini hidup bergerombol dan menyukai perairan yang berlumpur. Ikan ini termasuk ikan karnivora, makanannya berupa udang kecil dan ikan kecil. Ikan Tigawaja merupakan salah satu sumberdaya ikan yang dapat pulih (renewable resoursces), namun apabila pengelolaannya tidak secara tepat maka akan terjadi penurunan stok. penurunan stok pada ikan di perairan dapat dipengaruhi oleh aktivitas penangkapan.

Penelitian ini dilaksanakan pada bulan Juni 2016, dengan tujuan untuk mengetahui hubungan panjangberat, faktor kondisi, ukuran pertama kali ikan yang tertangkap (L50\%), Tingkat Kematang Gonad (TKG), Indeks Kematangan Gonad (IKG), ukuran pertama kali matang gonad $\left(\mathrm{L}_{\mathrm{m} 50 \%}\right)$, fekunditas dan diameter telur.

\section{MATERI DAN METODE PENELITIAN}

\section{A. Materi Penelitian}

Materi yang digunakan pada penelitian ini adalah ikan Tigawaja (Johnius sp.) yang didaratkan di Tempat Pelelangan Ikan (TPI) Tawang Kendal, Kabupaten Kendal, Provinsi Jawa Tengah.

Alat yang digunakan yaitu timbangan elektik dengan ketelitian 0,1 gram untuk menimbang berat tubuh ikan, timbangan elektrik dengan ketelitian 0,01 untuk menimbang gonad ikan, kunci TKG menurut Cassie untuk mengidentifikasi kematangan gonad ikan, alat sectio untuk membedah ikan, alat tulis untuk mencatat hasil penelitian, sedgwick rafter dengan ketelitian $1 \mathrm{~mm}$ untuk tempat peletakan telur ikan, gelas beker ukuran $250 \mathrm{ml}$ untuk tempat pengadukan gonad ikan dan aquades, pengaduk untuk mengaduk gonad ikan, pipet tetes untuk mengambil telur yang sudah diencerkan, botol sampel untuk tempat gonad ikan, penggaris dengan ketelitian 1 mm untuk mengukur panjang ikan, hand counter untuk menghitung jumlah telur yang diamati di mikroskop, Mikroskop binokuler untuk mengamati jumlah telur, kertas folio untuk mencatat hasil laporan, kamera untuk dokumentasi selama penelitian berlangsung.

Bahan yang digunakan dalam penelitian ini adalah ikan Tigawaja, alkohol 70\% untuk mengawetkan gonad, aquadest untuk mengencerkan gonad, es untuk mengawetkan ikan, pupuk urea sebagai pengganti larutan gilson untuk melarutkan dinding gonad sehingga butiran telur terlepas.

\section{B. Metode Penelitian}

Metode yang digunakan dalam penelitian ini adalah metode survei. Menurut Arikunto (2006) menyatakan bahwa metode survei bertujuan untuk mencandra gejala yang ada serta mencari informasi factual yang mendetail dan justifikasi atau kebenaran keadaan yang terjadi, membuat komparasi dan evaluasi, serta belajar dari pengalaman orang lain. variabel yang akan diukur adalah aspek biologi dari Ikan Tigawaja yang didaratkan di PPP Tawang Kabupaten Kendal.

\section{a).Metode Sampling Penentuan Kapal}

Penentuan kapal sampel mengikuti prosedur yang dikemukakan oleh Sadhotomo dan Potier (1991) dalam Sulistyawati (2009) seperti berikut ini :

a. Jika kapal yang mendarat kurang dari 5 buah, dipilih 1 kapal yaitu kapal nomor 1 .

b. Jika kapal yang datang lebih dari 5 buah, maka dipilih 2 buah kapal sebagai sampel. Kapal sampel pertama adalah kapal nomor urut 1 dari daftar nomor urut kapal. Kapal sampel kedua adalah kapal nomor 2 yang daerah penangkapanya berbeda dengan nomor 1. Jika daerah penangkapanya sama dengan kapal nomor 1, maka kapal sampel kedua adalah kapal nomor berikutnya dengan daerah penangkapan yang berbeda dengan kapal nomor 1, dan seterusnya jumlah kapal sampel mengikuti kelipatan 5.

\section{b).Metode Pengambilan Sampel.}

Pengambilan sampel dilakukan selama satu bulan pada bulan Juni 2016. Teknik pengambilan sampel yang digunakan dalam penelitian ini adalah Purposive sampling. Pengambilan sampel dilakukan selama satu bulan yaitu pada bulan Juni sebanyak 4 kali, dimana jumlah ikan contoh diambil 10\% dari jumlah hasil tangkapan, dengan pertimbangan bahwa dari pengambilan sampel sebanyak $10 \%$ tersebut diharapkan dapat mewakili populasi Ikan Tigawaja (Sugiharto, 2009 dalam Rahman et al., 2013). Pengukuran panjang dan berat ikan contoh serta pengambilan gonad dilakukan di lapangan dan kemudian dianalisis lebih lanjut di Laboratorium Pengelolaan Sumberdaya Ikan dan Lingkungan, Fakultas Perikanan dan Ilmu Kelautan. Gonad diawetkan dengan alkohol 70\% agar gonad tidak mengalami kerusakan. Perhitungan fekunditas mengikuti saran dari Sugiharto (2009) dalam Rahman et al., (2013), bilamana sampel sebesar 10\% dari populasi dianggap terlalu besar (lebih dari 30) maka alternatif yang bisa digunakan adalah mengambil sampel sebanyak 30 individu.

\section{c).Analisis Data}

a. Hubungan Panjang Berat berikut ini:

Analisis hubungan panjang berat yang digunakan oleh Effendi (2002), dapat dinyatakan dalam persamaan

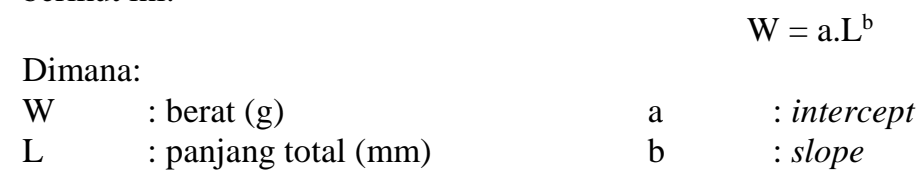

Persamaan tersebut dapat digambarkan dalambentuknlinier dengan logaritma digunakan persamaan :

(C) Copyright by Management of Aquatic Resources (MAQUARES) 
$\log \mathrm{W}=\log \mathrm{a}+\mathrm{b} \log \mathrm{L}$.

Jika nilai $\mathrm{b}<3$ atau $\mathrm{b}>3$ disebut pola pertumbuhan allometrik, dimana nilai $\mathrm{b}<3$ disebut allometrik negatif, sedangkan nilai $b>3$ disebut allometrik positif, dan jika nilai $b=3$ disebut pola pertumbuhan isometrik (Effendi, 2002).

\section{b. $\quad$ Faktor Kondisi}

faktor kondisi diitung berdasarkan hubungan panjang dan berat menggunakan rumus sebagai berikut :

$$
\mathrm{Kn}=\frac{\mathrm{W}}{\mathrm{aL}^{\mathrm{b}}}
$$

Dimana:

$$
\begin{array}{lll}
\mathrm{Kn} & =\text { Faktor kondisi relatif } & \mathrm{a}=\text { konstanta } \\
\mathrm{W} & =\text { bobot tubuh ikan }(\text { gram }) & \mathrm{b}=\text { intercept } \\
\mathrm{L} & =\text { panjang ikan }(\mathrm{mm}) &
\end{array}
$$

c. Ukuran Pertama Kali Tertangkap (L50\%)

Ukuran rata-rata ikan tertangkap didapatkan dengan cara memplotkan frekuensi kumulatif dengan setiap panjang ikan, sehingga akan diperoleh kurva logistik baku dan titik potong antara kurva dengan $50 \%$ frekuensi kumulatif adalah panjang saat 50\% ikan tertangkap (Saputra, 2009).

\section{d. Indeks Kematangan Gonad (IKG)}

Menurut Effendi (2002), indeks kematangan gonad (IKG) dihitung dengan membandingkan bobot gonad dengan bobot tubuh ikan tersebut dikalikan $100 \%$ rumus yang digunakan adalah sebagai berikut :

$$
\mathrm{IKG}=\mathrm{BG} \times 100 \%
$$

BT

Dimana:

IKG $\quad=$ indeks kematangan gonad $(\%)$

BG = berat gonad ikan $(\mathrm{g})$

BT $\quad=$ berat tubuh ikan $(\mathrm{g})$

\section{e. Ukuran Pertama Kali Matang Gonad}

Ukuran pertama kali ikan matang gonad diperoleh dengan mencari nilai Lm50\% dengan cara memplotkan persentase kumulatif ikan matang gonad dengan ukuran panjang tubuh ikan, sehingga akan diperoleh kurva logistik baku dan titik potong antara kurva dengan 50\% frekuensi kumulatif adalah panjang saat $50 \%$ ikan pertama kali matang gonad.

\section{f. Fekunditas}

Menurut Effendi (2002), Fekunditas dapat diperoleh menggunakan rumus sebagai berikut:

$$
\mathrm{F}=\frac{(\mathrm{G} \times \mathrm{V} \times \mathrm{X})}{\mathrm{Q}}
$$

Dimana:

$\mathrm{F}=$ fekunditas (butir telur) $\quad \mathrm{G}=$ bobot gonad total (gram)

$\mathrm{V}=$ volume pengenceran $(\mathrm{ml}) \quad \mathrm{X}=$ jumlah telur yang ada dalam $1 \mathrm{cc}$ (butir)

$\mathrm{Q}=$ bobot telur contoh (gram)

Fekunditas sering dihubungkan dengan panjang dan berat, menurut King (1978) dalam Iswari (2014), hubungan fekunditas dengan panjang dan berat digambarkan dengan persamaan:

$\mathrm{F}=\mathrm{a} \cdot \mathrm{Lb}$

$\mathrm{F}=\mathrm{a} \cdot \mathrm{Wb}$

dimana:

$\mathrm{F}=$ fekunditas

$\mathrm{L}=$ Panjang ikan $(\mathrm{mm})$

$\mathrm{W}=$ Berat ikan $($ gram $)$

$$
\begin{aligned}
& \mathrm{a}=\text { intercept } \\
& \mathrm{b}=\text { slope }
\end{aligned}
$$

\section{g. $\quad$ Diameter telur}

Diameter telur diamati dengan cara mengambil gonad ikan contoh TKG III dan IV. Diameter telur diukur dengan menggunakan mikroskop elektrik. Telur yang sudah dihitung fekunditasnya kemudian diukur diameternya dibawah mikroskop dengan perbesaran 40 kali dengan bantuan mikrometer okuler.

\section{HASIL DAN PEMBAHASAN}

A. Aspek Pertumbuhan Ikan Tigawaja (Johnius sp)

\section{a. Struktur Ukuran ikan}

Berdasarkan penelitian hasil sampling diperoleh 390 ekor Ikan Tigawaja . Panjang ikan Tigawaja berkisar antara 10,5-20,9 cm dan berat berkisar antara 14-124 gram. Struktur ukuran ikan Tigawaja dapat dilihat pada Gambar 1 . 


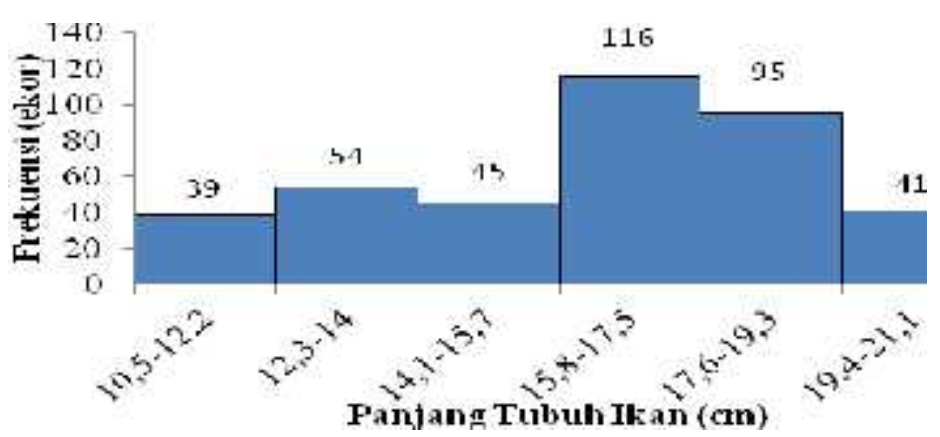

Gambar 1. Histrogram Struktur Ukuran Ikan Tigawaja

Ukuran Ikan Tigawaja yang paling banyak tertangkap berkisar antara 15,8-17,5 cm dengan frekuensi 166 ekor, yang paling sedikit tertangkap berkisar antara 10,5-12,2 cm dengan frekuensi 39 ekor.

\section{b. Ukuran Pertama Kali Tertangkap ( $\left.\mathbf{L}_{50} \%\right)$}

Ukuran rata-rata tertangkap dapat dilihat dari titik tengah $50 \%$ hasil tangkapan. Ikan Tigawaja pada sampel penelitian diperoleh ukuran rata-rata tertangkapnya $16,4 \mathrm{~cm}$ dengan kisaran ukuran ikan sampel penelitian adalah $10,5 \mathrm{~cm}-20,9 \mathrm{~cm}$, dapat dilihat pada Gambar 2 .

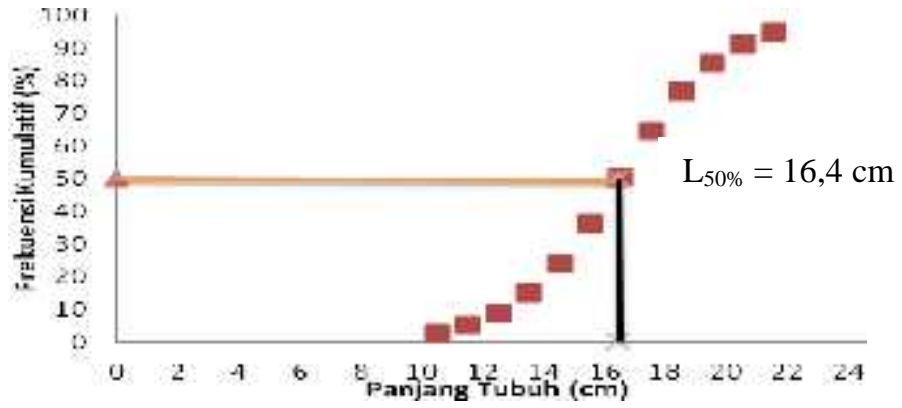

Gambar 2. Ukuran Pertama Kali Tertangkap (L50\%) Ikan Tigawaja

Ukuran pertama kali Ikan Tigawaja $\left(\mathrm{L}_{50 \%}\right)$ adalah $16,4 \mathrm{~cm}$. Nilai $\mathrm{L} \infty$ sebesar $21,8 \mathrm{~cm}$ dan nilai $1 / 2 \mathrm{~L} \infty 10,9$ $\mathrm{cm}$, ini berarti ukuran ikan yang tertangkap masih cukup besar dan layak tangkap, karena $\mathrm{L}_{50 \%}>\mathrm{L} \propto$. Ukuran rata-rata tertangkap idealnya tidak lebih kecil dari setengah panjang infinitinya (Saputra, 2009).

\section{c. Hubungan Panjang Berat}

Sampel ikan yang digunakan dalam pengukuran panjang berat sebanyak 390 ekor, dengan kisaran panjang 105-209 $\mathrm{mm}$. Berdasarkan hasil perhitungan hubungan panjang berat menggunakan analisis regresi dari data komposisi ukuran ikan, diperoleh persamaan sebesar $\mathrm{W}=0,00003 \mathrm{~L}^{2,8559}$. Dari persamaan tersebut didapatkan nilai a sebesar 0,00003 dan nilai b sebesar 2,8559. Selanjutnya dilakukan uji $t$ dan diperoleh $\mathrm{T}$ hitung $>\mathrm{T}$ tabel, maka Ho ditolak. Nilai b yang didapatkan kurang dari 3, hal tersebut menunjukan bahwa pertambahan panjang lebih cepat daripada pertambahan beratnya, sehingga termasuk dalam allometrik negatif.

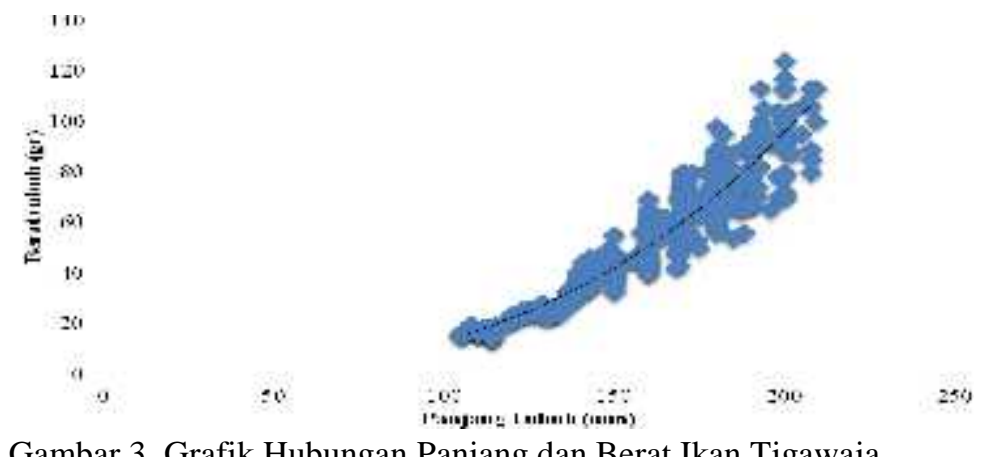

Gambar 3. Grafik Hubungan Panjang dan Berat Ikan Tigawaja

Koefisien korelasi (r) hubungan panjang berat tubuh ikan Tigawaja yaitu 0,927 dimana nilai tersebut menunjukan bahwa hubungan panjang berat tubuh ikan Tigawaja memiliki korelasi yang tinggi, ini berarti apabila panjang bertambah maka berpengaruh terhadap pertambahan berat tubuhnya. Menurut Omar (2005) dalam Suwarni (2009) yang menyatakan apabila nilai koefisien korelasi 0,90 - 1,00 menunjukkan korelasi yang sangat kuat.

\section{d. Faktor Kondisi}

Faktor Kondisi merupakan keadaan yang menggambarkan kegemukan atau kemontokan ikan dengan angka (Effendi, 2002). Nilai faktor kondisi pada ikan tigawaja selama penelitian adalah 0,94 yang menunjukan 
bahwa ikan Tigawaja yang tertangkap selama penelitian memiliki bentuk badan pipih. Menurut Effendi (2002), ikan-ikan yang badannya kurang pipih, nilai $\mathrm{K}$ itu berkisar antara 1-3.

\subsection{Aspek Reproduksi}

a. Tingkat Kematangan Gonad (TKG)

Pengamatan tingkat kematangan gonad pada ikan Tigawaja menggunakan metode dari Cassie. Tingkat Kematang Gonad (TKG) ikan jantan dan betina yang diamati tingkat kematangan gonadnya selama penelitian berjumlah masing-masing 54 dan 46 ekor. Tingkat kematangan gonad pada ikan Tigawaja jantan maupun betina selama penelitian tersaji pada Tabel 1 .

Tabel 1. Pengamatan Gonad Ikan Tigawaja Jantan dan Betina

\begin{tabular}{ccc}
\hline TKG & \multicolumn{2}{c}{ Persentase TKG (\%) } \\
\cline { 2 - 3 } & Jantan & Betina \\
\hline I & 19 & 28 \\
II & 43 & 15 \\
III & 20 & 39 \\
IV & 19 & 17 \\
V & - & -
\end{tabular}

Sumber : Hasil Penelitian

Berdasarkan pengamatan secara morfologi selama bulan Juni dari 54 sampel Tigawaja jantan didominasi oleh TKG II dengan nilai 43\%, sedangkan 46 sampel betina didominasi oleh TKG III dengan nilai 39\%.Hasil penelitian Sumartini (2003) di Perairan Kendal yang dilakukan pada bulan Agustus, Ikan Tigawaja Betina didominasi oleh TKG III. Hasil penelitian Jasman (2004) yang dilakukan di perairan Tegal pada bulan AgustusSeptember Ikan Tigawaja betina didominasi oleh TKG IV. Dengan demikian dapat diduga bahwa stok ikan Tigawaja pada bulan Juni - September memasuki musim pemijahan.

\section{b. Indeks Kematangan Gonad (IKG)}

Indeks Kematangan Gonad (IKG) merupakan suatu cara untuk mengetahui perkembangan gonad pada setiap kematangan gonad secara kuantitatif. Data kisaran IKG ikan Tigawaja jantan dan betina tersaji pada Tabel 2.

Tabel 2. Nilai Indeks Kematangan Gonad Rata-rata dari Ikan Jantan dan Betina.

\begin{tabular}{ccccc}
\hline \multirow{2}{*}{ TKG } & \multicolumn{2}{c}{$\operatorname{IKG}(\%)$} & \multicolumn{2}{c}{ Rata-rata IKG $(\%)$} \\
\cline { 2 - 5 } & jantan & betina & jantan & betina \\
\hline I & $0,15-0,29$ & $0,41-0,65$ & 0,209 & 0,49 \\
II & $0,15-0,36$ & $0,13-3,29$ & 0,234 & 2,08 \\
III & $0,19-0,46$ & $1,30-6,15$ & 0,333 & 3,24 \\
IV & $0,28-0,45$ & $2,31-7,44$ & 0,366 & 6,01 \\
\hline
\end{tabular}

\section{Sumber : Hasil Penelitian}

Nilai IKG ikan Tigawaja jantan maupun betina mengalami peningkatan mengikuti perkembangan tingkat kematangan gonad. Nilai IKG tertinggi pada ikan jantan yaitu $0,395 \%$ dengan panjang $150 \mathrm{~mm}$, sedangkan nilai IKG terendah $0,154 \%$ dengan panjang $170 \mathrm{~mm}$. Nilai IKG tertinggi pada ikan betina 7,44\% dengan panjang $180 \mathrm{~mm}$, sedangkan terendah yaitu $0,40 \%$ dengan panjang $188 \mathrm{~mm}$.

Nilai IKG yang diperoleh yaitu < 20\%, yang mengindikasikan bahwa ikan Tigawaja merupakan kelompok ikan yang bernilai IKG kecil dan dikategorikan sebagai ikan yang dapat memijah lebih dari satu kali tiap tahunnya. Hal ini sesuai dengan Yustina (2002) dalam Mariskha (2012), menyatakan bahwa ikan yang mempunyai nilai IKG lebih kecil dari $20 \%$ adalah kelompok ikan yang dapat memijah lebih dari satu kali setiap tahunnya.

\section{c. Ukuran Pertama Kali Matang Gonad}

Ukuran pertama kali matang gonad (Lm50\%) Ikan Tigawaja jantan sebesar $18 \mathrm{~cm}$ dan Ikan Tigawaja betina sebesar $17,5 \mathrm{~cm}$. Untuk mengetahui kondisi ikan pertama kali tertangkap apakah telah matang gonad atau belum, maka perlu dilakukan perbandingan antara nilai panjang pertama kali tertangkap (Lc50\%) dengan panjang pertama kali matang gonad (Lm50\%). Nilai L50\% yang didapatkan selama penelitian sebesar 16,4 cm., sehingga $\mathrm{L}_{50 \%}<\mathrm{Lm}$. Dari perbandingan tersebut menggambarkan bahwa ikan tertangkap sebagian besar belum matang gonad, sehingga atau belm memijah untuk yang pertama kalinya.

\section{d. Fekunditas}

Fekunditas adalah jumlah telur ikan betina sebelum dikeluarkan pada waktu akan memijah. Pengamatan fekunditas ikan Tigawaja berkisar 15.500 - 44.148 butir. Dengan kisaran panjang $14 \mathrm{~cm}-20,9 \mathrm{~cm}$. Menurut Effendi (2002) fekunditas mempunyai hubungan atau keterkaitan dengan umur, panjang atau bobot tubuh, dan 
spesies ikan. Grafik hubungan antara fekunditas dengan panjang tubuh dan fekunditas dengan berat tubuh tersaji pada Tabel 3.

Tabel 3. Hasil Uji Korelasi Pearson Hubungan Panjang Tubuh dengan Fekunditas dan Hubungan Berat Tubuh dengan Fekunditas

\begin{tabular}{ccc}
\hline Analisa uji & $\boldsymbol{r}$ & Sig. (2-tailed) \\
\hline Panjang dengan Fekunditas & 0,134 & 0,515 \\
Berat dengan Fekunditas & 0,641 & 0,000 \\
\hline
\end{tabular}

*)Nyata pada taraf 0,05

Berdasarkan hasil yang terdapat pada Tabel 4, didapatkan hasil korelasi pearson antara panjang tubuh dengan fekunditas dan berat tubuh dengan fekunditas. Pada hasil tersebut dinyatakan ada hubungan antara nilai variabel dengan nilai a $<0,05$ yaitu memiliki perbedaan nyata. Hubungan antara panjang tubuh dengan fekunditas didapatkan hasil $a>0,05$ yang berarti bahwa hubungan antara panjang dengan fekunditas sangat lemah. Hasil hubungan antara berat tubuh dengan fekunditas didapatkan nilai $a<0,05$ dengan nilai r 0,641 , ini berarti bahwa ada hubungan yang cukup antara berat tubuh dengan fekunditas.

\section{e. Diameter Telur}

Diameter telur Ikan Tigawaja (Johnius sp.) berkisar antara 0,05 $\mathrm{mm}-0,45 \mathrm{~mm}$. Diameter telur TKG III menyebar pada kisaran $0,05 \mathrm{~mm}-0,4 \mathrm{~mm}$, sedangkan diameter telur IV menyebar pada kisaran $0,1 \mathrm{~mm}-0,45$ mm. hasil lengkapnya dapat dilihat Gambar 5 dan Gambar 6.

\section{TKG III}

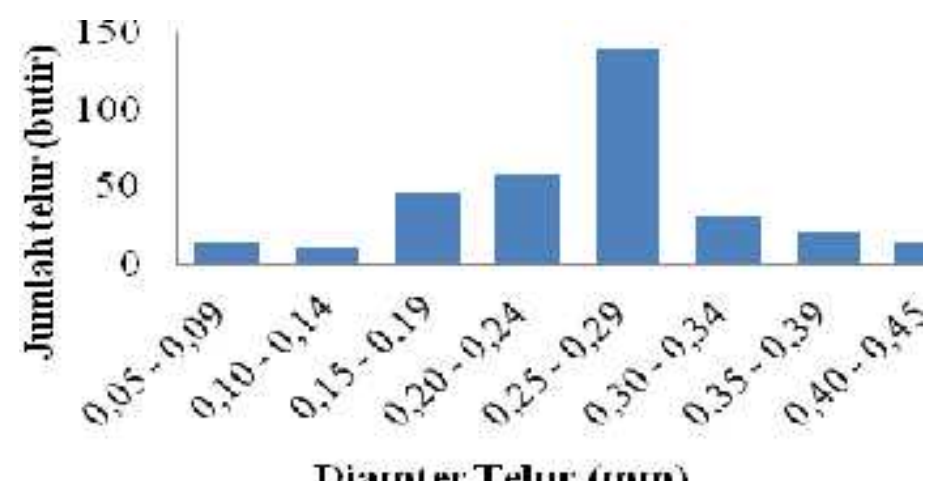

Gambar 6. Sebaran Diameter Telur Ikan Tigawaja TKG III

\section{TKG IV}

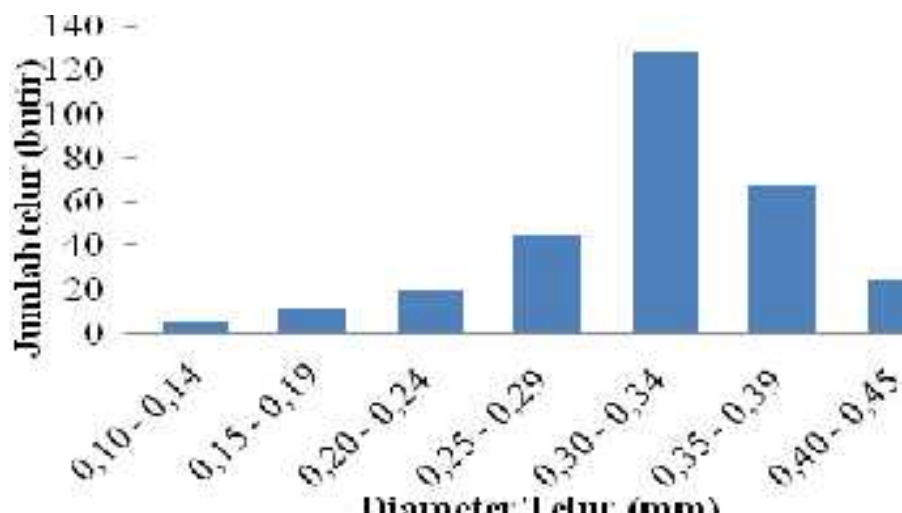

Gambar 7. Sebaran diamter telur Ikan Tigawaja TKG IV

Dari gambar di atas menunjukan terjadinya peningkatan ukuran diameter telur dari TKG III ke TKG IV. Menurut Effendie (2002) yang menyatakan bahwa, semakin tinggi tingkat kematangan gonad maka diameter telur yang ada di dalam ovarium akan semakin besar. Ukuran diameter telur Ikan Tigawaja yang didapat dari hasil penelitian ini beraneka ragam ukuran, hal ini menunjukkan bahwa Ikan Tigawaja melakukan pemijahan secara parsial atau tipe pemijahan yang panjang. 


\section{KESIMPULAN}

Berdasarkan hasil penelitian yang telah dilakukan dapat diambil kesimpulan bahwa Ikan Tigawaja (Johnius sp.) tertangkap pada kisaran panjang 10,5-20,9 $\mathrm{cm}$. Pertumbuhan ikan Tigawaja di TPI Tawang bersifat allometrik negatif. Faktor kondisi yang diperoleh sebesar 0,94 yang berarti ikan Tigawaja memiliki tubuh kurang pipih. Ukuran pertama kali tertangkap ikan Tigawaja pada ukuran $16,4 \mathrm{~cm}$ dimana ukuran tersebut adalah ukuran yang layak tangkap berdasarkan nilai $\mathrm{L}_{50 \%}>1 / 2 \mathrm{~L} \infty$, ukuran pertama kali matang gonad yaitu pada ikan jantan 18 $\mathrm{cm}$ dan betina $17,5 \mathrm{~cm}$. Tingkat Kematangan Gonad ikan Tigawaja jantan didominasi oleh TKG II dan betina didominasi oleh TKG III, dengan Indeks Kematangan Gonad ikan Tigawaja berkisar antara 0,154\%-7,44\%. Nilai fekunditas ikan Tigawaja berkisar 15.500 - 44.148 butir, dengan kisaran panjang 140-209mm dan ukuran diameter telur Ikan Tigaja berkisar antara $0,05 \mathrm{~mm}-0,45 \mathrm{~mm}$.

\section{UCAPAN TERIMAKASIH}

Ucapan terimakasih ditujukan kepada Drs. Ign. Boedi Hendrarto M.Sc, Ph.D., Churun Ain, S.Pi., M.Si., Dr. Ir. Pujiono Wahyu P., MS., yang telah memberikan masukan, kritik dan saran yang sangat berarti bagi penulis. Kepada Dinas Kelautan dan Perikanan Kabupaten Kendal dan Pegawai Pelabuhan Perikanan Pantai (PPP) Tawang Kabupaten Kendal yang telah membantu dan memberikan informasi.

\section{DAFTAR PUSTAKA}

Arikunto. 2006. Prosedur Penelitian suatu Pendekatan Praktek. Edisi Revisi. PT Rineka Cipta, Jakarta.

Budiman, Supriharyono dan Asriyanto. 2006. Analisis Sebaran Ikan Demersal Sebagai Basis Pengelolaan Sumberdaya Pesisir Di Kabupaten Kendal. J.Pasir Laut. 2 (1) : 52-53.

Effendi, M.I. 2002. Biologi Perikanan. Yogyakarta: Yayasan Pustaka Nusatama.

Hasan. M. I. 2002. Pokok-pokok Materi Metodologi Penelitian dan Aplikasinya. Ghalia Indonesia. Bogor.

Iswari, K.W., S.W. Saputra, A. Solichin. 2014. Analisis Aspek Biologi Ikan Kuniran (Upeneus spp) Berdasarkan Jarak Operasi Penangkapan Alat Tangkap Cantrang di Perairan Kabupaten Pemalang. Fakultas Perikanan Dan Ilssmu Kelautan. Universitas Diponegoro. Semarang. Journal of Maquares. 3 (4): 83-91.

Jasman, Thimotius. 2004. Perikanan Bundes (Danish seine) dan Dampaknya Terhadap Kelestarian Stok Ikan di Perairan Kota Tegal. [Tesis]. Program Pascasarjana. Universitas Diponegoro. Semarang.

Mariskha, P.R. dan N. Abdulgani. 2012. Aspek Reproduksi Ikan Kerapu Macan (Epinephelus sexfasciatus) di Perairan Glodonggede Tuban. Fakultas Matematika dan Ilmu Pengetahuan Alam. Institut Teknologi Sepuluh Nopember (ITS). Jurnal Sains dan Seni ITS. 1(1):27-31.

Notoatmodjo, S. 2002. Metodologi Penelitian Kesehatan. Rineka Cipta. Jakarta.

Rahman, D.R., I. Triarso dan Asriyanto. 2013. Analisis Bioekonomi Ikan Pelagis Pada Usaha Perikanan Tangkap di pelabuhan Perikanan Pantai Tawang Kabupaten Kendal. Journal of Fisheries Resources Utilization Management and Tecnology. 2(1):1-10.

Saputra, S. W. 2009. Dinamika Populasi Ikan Berbasis Riset. Universitas Diponegoro. Semarang. 203 hlm.

Sumartini, S. 2003. Kajian Penggunaan Jaring Arad terhadap Sumberdaya Ikan Demersal di Perairan Pantai Kota Tegal. [Tesis]. Program Pascasarjana. Universitas Diponegoro. Semarang. 